Vol. 1 No. 1 Januari 2022, e-ISSN : 2827-8070 | p-ISSN : 2827-8240

\title{
PERSEPSI MASYARAKAT TERHADAP HIV/AIDS DAN ODHA SEBAGAI UPAYA UNTUK MENURUNKAN STIGMA MASYARAKAT TERHADAP PENDERITA HIV/AIDS DI DESA KREBET KECAMATAN PILANGKENCENG KABUPATEN MADIUN TAHUN 2016
}

\author{
DONY NOERLIANI \\ UPT Pelatihan Kesehatan Masyarakat Murnajati Jawa Timur \\ e-mail: donynoerliani@gmail.com
}

\begin{abstract}
ABSTRAK
Penyakit HIV/AIDS merupakan issue sensitive dibidang kesehatan. Meskipun upaya untuk menekan laju kematian akibat AIDS dapat dikendalikan namun penemuan baru infeksi HIV dan kasus AIDS masih terus bertambah. Salah satu kendala dalam pengendalian penyakit HIV/AIDS adalah stigma dan diskriminasi terhadap penderita AIDS. Bila stigma dan diskriminasi dampak dari kesalahan persepsi tentang HIV/AIDS terus terjadi di masyarakat akan berdampak cukup signifikan terhadap penanggulangan HIV/AIDS. Tujuan dari penelitian ini untuk mengetahui persepsi masyarakat tentang HIV/AIDS dan ODHA di desa Krebet kecamatan Pilangkenceng Kabupaten Madiun. Rancangan penelitian yang digunakan adalah deskriptif. Populasi adalah warga desa Krebet Kecamatan Pilang Kenceng kabupaten Madiun dengan jumlah sampel $10 \%$ dari jumlah populasi yang ada dengan criteria sampel yaitu warga desa Krebet yang dapat membaca dan menulis dengan rentang usia 17 tahun keatas. Teknik sampling yang digunakan Consecutive sampling. Penelitian dilaksanakan mulai bulan Februari sampai dengan bulan Agustus 2016. Instrument untuk pengumpulan data adalah kusioner. Data umum dianalisis dengan cara frekwensi jawaban dibandingkan dengan jumlah responden yang ada kemudian dikalikan $100 \%$ dan hasilnya berupa prosentase. Data khusus dianalisis dengan score- $\mathrm{T}$, persepsi dinyatakan positif (favorable) apabila nilai $\mathrm{T} \geq$ Mean $\mathrm{T}$ dan persepsi dinyatakan negative ( unfavorable) apabila nilai $\mathrm{T}<$ Mean T. Persespsi masyarakat desa Krebet tentang penyakit HIV/AIDS pada sub aspek pengertian HIV/AIDS berpersepsi negatif, sub aspek penyebab penyakit HIV/AIDS berpersepsi positif, sub aspek cara penularan HIV/AIDS berpersepsi negatif dan sub aspek pencegahan HIV/Aids berpersepsi positif. Persespsi masyarakat desa Krebet tentang Odha pada sub aspek keberadaan Odha masyarakat Krebet berpersepsi positif dan sub aspek stigma terhadap Odha berpersepsi negatif. Bentuk stigma yang dilakukan masyarakat yaitu pernyataan bahwa Odha harus dijauhi $(35,59 \%)$, pernyataan bahwa Odha harus diusir $(29,12 \%)$, pernyataan bahwa Odha adalah orang yang tidak mampu untuk berkarya dan bekerja $(38,53 \%)$, pernyataan bahwa Odha tidak perlu dilibatkan dalam kegiatan di masyarakat (38,55\%). Masyarakat desa Krebet masih berpersespsi negatif tentang pengertian penyakit HIV/AIDS dan cara penularannya. Sebagian masyarakat desa Krebet masih mempunyai stigma negatif terhadap keberadaan Odha. Pemerintah setempat khususnya Dinkes kabupaten Madiun perlu melakukan penyuluhan dan sosialisasi yang intensif tentang HIV/AIDS sebagai upaya pencegahan dan penanggulangan penyakit HIV/AIDS dan sebagai langkah awal untuk memperbaiki stigma negatif dan diskriminasi terhadap Odha di kabupaten Madiun, mengingat desa Krebet termasuk dalam wilayah kecamatan Pilang Kenceng yang merupakan tiga besar kasus terbanyak penyakit HIV/AIDS di kabupaten Madiun.
\end{abstract}

Kata Kunci : Persepsi, Penyakit HIV/AIDS dan ODHA, Stigma Masyarakat

\section{PENDAHULUAN}

Penyakit HIV/AIDS merupakan issue sensitive dibidang kesehatan. HIV/AIDS telah menjadi issue internasional karena HIV/AIDS telah menyerang manusia hampir diseluruh penjuru dunia. HIV/AIDS merupakan new emerging disease dan merupakan pandemic di Indonesia. Meskipun upaya untuk menekan laju kematian akibat AIDS dapat dikendalikan namun penemuan baru infeksi HIV dan kasus AIDS masih terus bertambah. 
Salah satu kendala dalam pengendalian penyakit HIV/AIDS adalah stigma dan diskriminasi terhadap penderita AIDS. Stigma dan diskriminasi tidak saja dilakukan oleh masyarakat awam yang tidak mempunyai pengetahuan yang cukup tentang penyakit HIV/AIDS tetapi juga dilakukan oleh kalangan masyarakat terpelajar dan dapat juga dilakukan oleh masyarakat yang paham betul tentang penyakit HIV/AIDS. Dimungkinkan stigma dan diskriminasi terhadap penderita HIV/AIDS timbul karena factor resiko penyakit ini yang terkait dengan perilaku seksual yang menyimpang dan penyalahgunaan Napza, masyarakat menganggap Odha sebagai sampah masyarakat, pengguna narkoba dan pelanggan lokalisasi. Banyak masyarakat yang masih salah persepsi tentang ODHA, mereka beranggapan siapapun yang sudah terkena HIV/AIDS harus dijauhi keberadaannya di lingkungan masyarakat atau dikucilkan di masyarakat sekitarnya.

Hasil study pendahuluan yang dilakukan secara acak terhadap 20 warga desa Krebet kecamatan Pilang Kenceng kabupaten Madiun yang dilakukan pada bulan Mei 2016 didapatkan hasil bahwa sebagian besar responden memiliki pemahaman yang kurang tentang penyakit HIV/AIDS khususnya pada penyebab HIV/AIDS dan cara penularannya demikian pula stigma masyarakat desa Krebet terhadap ODHA masih cukup tinggi, khususnya pada diskriminasi dengan menjauhi ODHA, sikap menyalahkan ODHA karena penyakitnya dan penolakan ODHA oleh masyarakat.

Stigma dan diskriminasi dari masyarakat tidak hanya terjadi pada Odha namun juga pada keluarganya (Ohidha), hasil penelitian Retno dkk, (2011) menyatakan bahwa keluarga Odha (Ohidha) menerima stigma dan diskriminasi yang terbanyak justru dari tetangga sendiri sebesar $14 \%$, stigma dari teman kerja sebesar $7 \%$, stigma dari lingkungan pekerjaan sebesar $5 \%$, stigma dari lingkungan sekolah sebesar $3 \%$ dan lingkungan ibadah sebesar 3\%.

Bila stigma dan diskriminasi dampak dari kesalahan persepsi tentang HIV/AIDS terus terjadi di masyarakat akan berdampak cukup signifikan terhadap penanggulangan HIV/AIDS. Dalam penelitian yang diterbitkan oleh journal of general internal medicine (2009) dalam Reynold ,2012), para peneliti fakultas pengobatan penyakit dalam dan penelitian layanan kesehatan di fakultas David Geffen School di UCLA AS menemukan bahwa sejumlah besar pasien HIV yang menerima stigma di masyarakat tidak mengakses perawatan dan kurang patuh terhadap ARV. Penelitian sejenis yang dilakukan oleh Noerliani D dkk,(2014) menyatakan stigma yang diterima Odha merupakan salah satu penghambat untuk patuh minum ARV.

Stigma dan diskriminasi masyarakat terhadap Odha dapat menimbulkan efek psikologis yang berat tentang bagaimana Odha melihat diri mereka sendiri, hal ini dapat mendorong terjadinya depresi dan keputusasaan yang selanjutnya dapat berdampak pada menurunnya semangat hidup Odha, dengan adanya stigma tersebut dapat mempertahankan odha untuk menyembunyikan statusnya. Hal ini tentunya akan sangat menghambat upaya pemerintah untuk penanggulangan penyakit HIV/AIDS. Pencegahan dan penanggulangan HIV/AIDS harus dilakukan secara komprehensif dalam arti penyelesaian kasus ini tidak hanya dalam satu sudut pandang medis saja melainkan harus melihat dan melibatkan persoalan lain yang berhubungan erat dengan permasalahan tersebut antara lain adalah stigma dan diskriminasi di masyarakat.

Selain hal tersebut diatas pemahaman yang kurang tepat tentang HIV/AIDS di masyarakat perlu diminimalkan agar penanganan HIV/AIDS bukan dengan cara memerangi pasien HIV/AIDS tetapi memerangi terjadinya cara penularan virus HIV. Dengan demikian focus penanggulangannya ditujukan pada upaya preventif. Upaya ini harus didukung dengan pengetahuan, sikap dan perilaku masyarakat yang menunjang tindakan tersebut karena pengetahuan dan persepsi masyarakat sering menjadi kendala pemberian dukungan pada pasien karena pengetahuan masyarakat yang salah.

\section{METODE PENELITIAN}

Rancangan penelitian yang digunakan dalam penelitian ini adalah deskriptif. Pada penelitian ini akan dideskripsikan persepsi masyarakat tentang penyakit HIV/AIDS dan ODHA 
serta mendeskripsikan bentuk stigma masyarakat terhadap ODHA di desa Krebet kecamatan Pilang Kenceng kabupaten Madiun.

Populasi pada penelitian ini adalah warga desa Krebet Kecamatan Pilang Kenceng kabupaten Madiun dengan jumlah sampel $10 \%$ dari jumlah populasi yang ada dengan jumlah minimal sampel 240 jiwa dengan criteria sampel sebagai berikut : warga desa Krebet yang dapat membaca dan menulis dengan rentang usia 17 tahun keatas. Teknik sampling yang digunakan adalah Consecutive sampling yaitu pemilihan sampel dengan menetapkan subjek yang memenuhi criteria penelitian dimasukkan dalam penelitian sampai kurun waktu tertentu, sehingga jumlah klien yang diperlukan terpenuhi. Penelitian dilaksanakan mulai bulan Februari 2016 sampai dengan bulan Agustus 2016.

Instrument yang digunakan untuk pengumpulan data dalam penelitian ini adalah kusioner yang diberikan pada warga desa Krebet kecamatan Pilang Kenceng Kabupaten Madiun setelah sebelumnya warga mengisi lembar persetujuan menjadi responden. Setelah data terkumpul semua dari hasil pengumpulan data, maka data umum yang meliputi umur dilakukan analisis dengan tehnik deskriptif statistic dengan tendensi sentral. Data umum yang meliputi pendidikan, pekerjaan, dan informasi dianalisis dengan cara frekwensi jawaban dibandingkan dengan jumlah responden yang ada kemudian dikalikan $100 \%$ dan hasilnya berupa prosentase. Data persepsi diukur dengan skala Likert, dan dianalisis dengan menggunakan score-T dengan hasil Persepsi dinyatakan positif (favorable) apabila nilai $\mathrm{T} \geq$ Mean $\mathrm{T}$ dan persepsi dinyatakan negative ( unfavorable) apabila nilai $\mathrm{T}<$ Mean $\mathrm{T}$.

\section{HASIL DAN PEMBAHASAN}

\section{Hasil}

\section{Sikap masyarakat desa Krebet terhadap keluarga Odha}

Tabel 1 Distribusi frekuensi responden berdasarkan sikap masyarakat desa Krebet Kab. Madiun terhadap keluarga ODHA tahun 2016

\begin{tabular}{clcc}
\hline No & Pernyataan sikap masyarakat & Frekuensi & Persentase (\%) \\
\hline 1. & Biasa & 150 & 44,1 \\
\hline 2. & Mendukung kesembuhan Odha & 34 & 10 \\
\hline 3 & Menjauhi dan mengucilkan Odha & 105 & 30,9 \\
\hline 4 & Tidak tahu harus bersikap & 32 & 9,4 \\
\hline 5 & Tidak mengucilkan & 19 & 5,6 \\
\hline & Jumlah & 340 & 100 \\
\hline
\end{tabular}

Tabel 1 menunjukkan bahwa 340 responden sebanyak $150(44,1 \%)$ masyarakat desa Krebet menyatakan sikap biasa dengan keluarga Odha dan Odha, sejumlah 105 (30,9\%) masyarakat desa Krebet menyatakan sikap menjauhi Odha dan keluarganya dan hanya sebagian kecil sejumlah $19(5,6 \%)$ responden menyatakan tidak mengucilkan terhadap Odha dan keluarga Odha .

\section{Upaya masyarakat desa Krebet untuk melindungi diri dan keluarga dari penyebaran virus HIV/Aids}

Tabel 2 Distribusi frekuensi responden berdasarkan upaya masyarakat desa Krebet Kab. Madiun untuk melindungi diri dan keluarga dari penyebaran virus HIV/AIDS tahun 2016

\begin{tabular}{cccc} 
No & $\begin{array}{c}\text { Upaya masyarakat untuk melindungi diri } \\
\text { dan keluarga dari penularan HIV/AIDS }\end{array}$ & Frekuensi & Persentase (\%) \\
\hline 1. & Menerapkan gaya hidup sehat & 57 & 16,8 \\
\hline
\end{tabular}


Vol. 1 No. 1 Januari 2022, e-ISSN : 2827-8070 | p-ISSN : 2827-8240

\begin{tabular}{clcc}
\hline 2. & Menjaga pergaulan / memilih teman & 57 & 16,8 \\
\hline 3 & Menjauhi Odha & 117 & 34,4 \\
\hline 4 & Setia pada pasangan & 59 & 17,3 \\
\hline 5 & Meningkatkan ibadah & 8 & 2,4 \\
\hline 6 & Biasa & 6 & 1,8 \\
\hline 7 & Tidak tahu & 29 & 8,5 \\
\hline 8 & Deteksi dini ke Puskesmas & 2 & 0,6 \\
\hline 9 & Menjauhi narkoba & 4 & 1,2 \\
\hline 10 & Jangan menjauhi Odha & 1 & 0,3 \\
\hline & Jumlah & 340 & 100 \\
\hline
\end{tabular}

Tabel 2 menunjukkan bahwa dari 340 responden sebanyak 117 (34,4\%) menyatakan upaya untuk melindungi diri dan keluarga dari penyebaran virus HIV/AIDS dengan menjauihi ODHA dan sejumlah 1 responden $(0,3 \%)$ menyatakan bahwa masyarakat jangan menjauhi ODHA.

\section{Persepsi masyarakat tentang HIV/AIDS di desa Krebet kecamatan Pilang Kenceng kabupaten Madiun}

Tabel 3 Distribusi frekuensi persepsi masyarakat tentang HIV/AIDS di desa Krebet kabupaten Madiun tahun 2016

\begin{tabular}{|c|c|c|c|c|c|c|}
\hline Sub Aspek & Pernyataan & $\begin{array}{l}\text { Sangat } \\
\text { setuju }\end{array}$ & setuju & $\begin{array}{l}\text { Tidak } \\
\text { setuju }\end{array}$ & $\begin{array}{l}\text { Sangat } \\
\text { tidak } \\
\text { setuju }\end{array}$ & Mean \\
\hline \multirow[t]{4}{*}{$\begin{array}{l}\text { Pengertian } \\
\text { HIV }\end{array}$} & $\begin{array}{l}\text { Penyakit HIV / AIDS adalah penyakit } \\
\text { kutukan }\end{array}$ & 4,12 & 21,5 & 63,2 & 11,2 & 2,81 \\
\hline & $\begin{array}{l}\text { Penyakit HIV/AIDS adalah penyakit } \\
\text { keturunan }\end{array}$ & 7,94 & 44,7 & 41,8 & 5,59 & 2,45 \\
\hline & Penyakit HIV/AIDS dapat disembuhkan & 11,8 & 55,6 & 27,6 & 5 & 2,26 \\
\hline & $\begin{array}{l}\text { Penyakit HIV /AIDS adalah penyakit yang } \\
\text { sangat mematikan } \\
\text { Mean komposit pengertian HIV }: 2,63\end{array}$ & 2,35 & 17,4 & 60 & 20,3 & 2,98 \\
\hline $\begin{array}{l}\text { Penyebab } \\
\text { penyakit } \\
\text { HIV }\end{array}$ & $\begin{array}{l}\text { Penyakit HIV/AIDS disebabkan oleh virus } \\
\text { yang dapat memperlemah kekebalan tubuh } \\
\text { manusia } \\
\text { Mean penyebab penyakit HIV }: 3,05\end{array}$ & 19,1 & 68,2 & 10,9 & 1,76 & 3,05 \\
\hline \multirow[t]{6}{*}{$\begin{array}{l}\text { Cara } \\
\text { penularan } \\
\text { HIV/AIDS }\end{array}$} & $\begin{array}{l}\text { Penularan HIV/AIDS melalui hubungan } \\
\text { seksual dengan pengidap HIV/AIDS tanpa } \\
\text { menggunakan kondom }\end{array}$ & 24,1 & 55 & 18,8 & 2,06 & 3,01 \\
\hline & $\begin{array}{l}\text { Penyakit HIV/AIDS dapat menular melalui } \\
\text { transfusi darah yang terinfeksi virus HIV }\end{array}$ & 22,94 & 57,65 & 16,76 & 2,65 & 3,01 \\
\hline & $\begin{array}{l}\text { Pemakaian jarum suntik, jarum akupuntur, } \\
\text { jarum tindik secara bersama sama dapat } \\
\text { sebagai perantara penularan HIV/AIDS }\end{array}$ & 21,2 & 56,8 & 20 & 2,06 & 2,97 \\
\hline & $\begin{array}{l}\text { Seorang ibu yang terkena HIV/AIDS dapat } \\
\text { menularkan penyakitnya pada anak yang } \\
\text { dikandungnya }\end{array}$ & 20,6 & 59,1 & 18,2 & 2,06 & 2,98 \\
\hline & $\begin{array}{l}\text { Bersentuhan, bersalaman dan berpelukan } \\
\text { dengan penderita HIV/AIDS dapat } \\
\text { menularkan penyakit HIV/AIDS }\end{array}$ & 5,29 & 34,7 & 55 & 5 & 2,60 \\
\hline & $\begin{array}{l}\text { Gigitan nyamuk dapat sebagai perantara } \\
\text { penularan penyakit HIV/AIDS }\end{array}$ & 3,24 & 47,6 & 44,7 & 4,41 & 2,50 \\
\hline
\end{tabular}


Vol. 1 No. 1 Januari 2022, e-ISSN : 2827-8070 | p-ISSN : 2827-8240

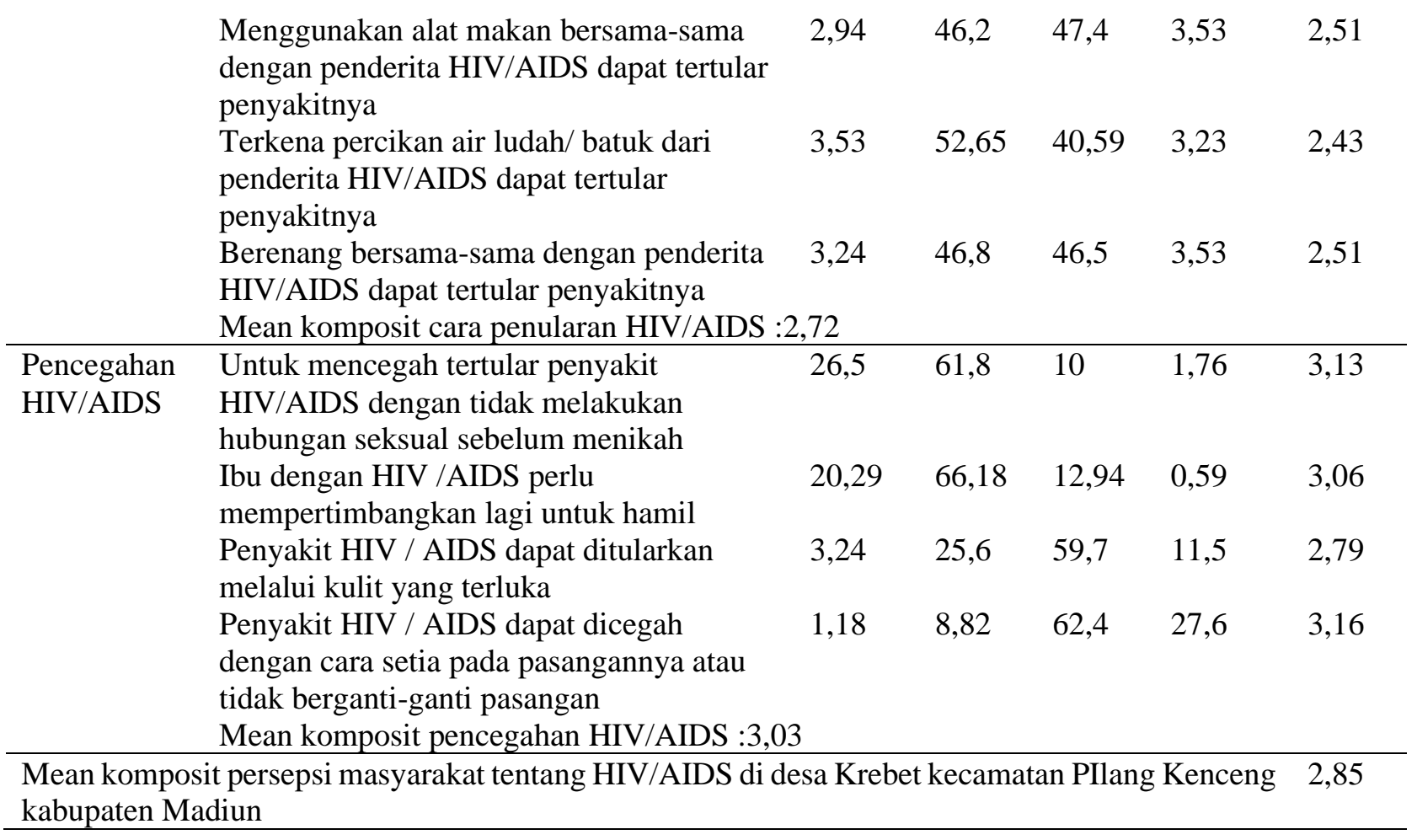

Berdasarkan table 3 menunjukkan bahwa persepsi masyarakat tentang HIV/AIDS di desa Krebet kecamatan Pilang Kenceng pada sub aspek pengertian HIV/AIDS negative. Masyarakat desa Krebet sebagian besar masih beranggapan bahwa penyakit HIV/AIDS adalah penyakit keturunan dan dapat disembuhkan. Sub aspek penyebab penyakit HIV/AIDS, masyarakat desa Krebet berpersepsi positif, sebagian besar 68,2 \% masyarakat tahu bahwa penyebab penyakit HIV/Aids adalah virus yang dapat memperlemah kekebalan tubuh manusia. Sub aspek cara penularan penyakit HIV/AIDS, masyarakat desa Krebet berpersepsi negative, masyarakat desa Krebet belum mengetahui secara benar penularan HIV/AIDS. Sub Aspek pencegahan penyakit HIV/AIDS masyarakat desa Krebet berpersepsi positif.

\section{Persepsi masyarakat tentang ODHA di desa Krebet kecamatan Pilang Kenceng kabupaten Madiun}

Tabel 4 Distribusi frekuensi persepsi masyarakat tentang ODHA di desa Krebet kabupaten Madiun tahun 2016

\begin{tabular}{|c|c|c|c|c|c|c|}
\hline Sub aspek & Pernyataan & $\begin{array}{l}\text { Sangat } \\
\text { setuju }\end{array}$ & setuju & $\begin{array}{l}\text { Tidak } \\
\text { setuju }\end{array}$ & $\begin{array}{l}\text { Sangat } \\
\text { tidak } \\
\text { setuju }\end{array}$ & Mean \\
\hline \multirow[t]{4}{*}{$\begin{array}{l}\text { Keberadaan } \\
\text { ODHA }\end{array}$} & $\begin{array}{l}\text { Orang dengan HIV/Aids adalah manusia } \\
\text { yang bermartabat sama dengan kita oleh } \\
\text { karena itu harus kita hormati }\end{array}$ & 18,5 & 67,9 & 12,6 & 0,88 & 3,04 \\
\hline & $\begin{array}{l}\text { Orang dengan HIV/Aids membutuhkan } \\
\text { dukungan keluarga dan masyarakat di } \\
\text { sekitarnya }\end{array}$ & 22,4 & 65,6 & 10,9 & 1,18 & 3,09 \\
\hline & $\begin{array}{l}\text { Orang dengan HIV/Aids dapat dijadikan } \\
\text { seorang teman yang baik }\end{array}$ & 3,2 & 26 & 64 & 7,4 & 2,75 \\
\hline & Mean komposit persepsi masyarakat tentang $\mathrm{l}$ & eberadaan & ODHA & 2,96 & & \\
\hline $\begin{array}{l}\text { Stigma } \\
\text { ODHA }\end{array}$ & $\begin{array}{l}\text { Saya malu bila mempunyai teman } \\
\text { seorang penderita HIV/AIDS }\end{array}$ & 1,47 & 27,6 & 60,9 & 10 & 2,79 \\
\hline
\end{tabular}


Vol. 1 No. 1 Januari 2022, e-ISSN : 2827-8070 | p-ISSN : 2827-8240

\begin{tabular}{|c|c|c|c|c|c|c|}
\hline & $\begin{array}{l}\text { Orang dengan HIV/Aids adalah aib bagi } \\
\text { lingkungan dan keluarga }\end{array}$ & 3,53 & 34,4 & 56,2 & 5,88 & 2,64 \\
\hline & $\begin{array}{l}\text { Orang dengan HIV/Aids adalah orang } \\
\text { yang salah dalam pergaulan }\end{array}$ & 14,4 & 57,4 & 25 & 3,24 & 2,17 \\
\hline & $\begin{array}{l}\text { Orang dengan HIV/Aids adalah orang } \\
\text { yang tidak bermoral agama }\end{array}$ & 9,41 & 45,9 & 40,6 & 4,12 & 2,39 \\
\hline & $\begin{array}{l}\text { Orang dengan HIV/Aids adalah } \\
\text { pelanggan lokalisasi }\end{array}$ & 10,6 & 58,8 & 29,4 & 1,18 & 2,21 \\
\hline & $\begin{array}{l}\text { Orang dengan HIV/Aids adalah } \\
\text { pengguna narkoba }\end{array}$ & 10,3 & 51,8 & 35,3 & 2,65 & 2,30 \\
\hline & $\begin{array}{l}\text { Orang dengan HIV/Aids adalah orang } \\
\text { yang menganut seks bebas }\end{array}$ & 21,2 & 55,3 & 22,4 & 1,18 & 2,04 \\
\hline & $\begin{array}{l}\text { Orang dengan HIV/Aids adalah } \\
\text { pembawa sial bagi keluarga }\end{array}$ & 6,18 & 36,8 & 49,1 & 7,94 & 2,59 \\
\hline & $\begin{array}{l}\text { Keluarga dari orang dengan HIV/Aids } \\
\text { harus dijauhi }\end{array}$ & 4,41 & 30,9 & 56,2 & 8,53 & 2,69 \\
\hline & \multicolumn{6}{|c|}{ Mean komposit persepsi masyarakat tentang stigma Odha : 2,42 } \\
\hline \multirow[t]{5}{*}{$\begin{array}{l}\text { Bentuk } \\
\text { stigma }\end{array}$} & $\begin{array}{l}\text { Orang dengan HIV/Aids adalah orang } \\
\text { yang harus dijauhi karena menularkan } \\
\text { penyakit yang mematikan }\end{array}$ & 5,29 & 30,3 & 57,6 & 6,76 & 2,66 \\
\hline & $\begin{array}{l}\text { Orang dengan HIV/Aids harus } \\
\text { diasingkan bila perlu diusir dari desa }\end{array}$ & 2,06 & 27,06 & 62,65 & 8,23 & 2,77 \\
\hline & $\begin{array}{l}\text { Saya sangat mendukung bila warga } \\
\text { mengusir orang dengan HIV/AIDS }\end{array}$ & 2,06 & 24,7 & 64,1 & 9,12 & 2,80 \\
\hline & $\begin{array}{l}\text { Orang dengan HIV/Aids adalah orang } \\
\text { yang tidak mampu lagi untuk berkarya } \\
\text { dan bekerja }\end{array}$ & 1,77 & 36,76 & 56,47 & 5 & 2,65 \\
\hline & $\begin{array}{l}\text { Orang dengan HIV/Aids tidak perlu } \\
\text { dilibatkan dalam kegiatan di masyarakat } \\
\text { Mean komposit persepsi masyarakat tentang }\end{array}$ & 2,65 & 35,9 & 55,9 & 5,59 & 2,64 \\
\hline
\end{tabular}

Mean komposit persepsi masyarakat tentang Odha di desa Krebet kecamatan PIlang Kenceng 2,69 kabupaten Madiun

Berdasarkan tabel 4 menunjukkan bahwa persepsi masyarakat tentang orang dengan HIV/AIDS (ODHA) pada sub aspek keberadaan ODHA, masyarakat desa Krebet berpersepsi positif, namun pada pernyataan bahwa ODHA dapat dijadikan seorang teman yang baik sejumlah 64 $\%$ responden menyatakan tidak setuju. Pada sub aspek stigma ODHA, masyarakat desa Krebet berpersepsi negative. Pada sub aspek bentuk stigma pada Odha, masyarakat desa Krebet berpersepsi positif, namun pada bentuk stigma ; Odha harus dijauhi karena menularkan penyakit yang mematikan sejumlah $30,3 \%$ responden menyatakan setuju, Odha adalah orang yang tidak mampu lagi untuk berkarya dan bekerja sejumlah $36,76 \%$ responden setuju, Odha tidak perlu dilibatkan dalam kegiatan di masyarakat

\section{Pembahasan}

Persepsi masyarakat tentang HIV/AIDS di desa Krebet kecamatan Pilang Kenceng kabupaten Madiun dari sub aspek pengertian HIV/AIDS masih negative, 44,7 \% masyarakat desa Krebet menyatakan bahwa penyakit HIV/AIDS adalah penyakit keturunan dan 55,6 \% masyarakat menyatakan penyakit HIV/AIDS dapat disembuhkan. Persepsi negative tersebut dapat disebabkan karena pengetahuan masyarakat desa Krebet yang kurang tentang penyakit HIV/AIDS hal ini dapat dimaklumi mengingat sebagian besar responden berpendidikan menengah ke bawah. Persepsi tentang penyebab penyakit HIV masyarakat desa Krebet berpersepsi positif, sebagian besar masyarakat sudah tahu bahwa penyakit HIV/AIDS 
disebabkan oleh virus yang dapat memperlemah kekebalan tubuh manusia. Pada sub aspek cara penularan penyakit HIV/AIDS masyarakat desa Krebet berpersepsi negative, masyarakat belum mengetahui secara benar cara penularan penyakit HIV/AIDS. Sub aspek pencegahan penyakit masyarakat desa Krebet berpersepsi positif.

Dari fenomena diatas terlihat jelas bahwa masyarakat desa Krebet masih perlu diberikan bekal pengetahuan tentang HIV/AIDS sebagai salah satu upaya pencegahan/penanggulangan penyakit HIV/AIDS dan sebagai langkah awal untuk memperbaiki stigma dan diskriminasi terhadap ODHA di kabupaten Madiun, mengingat desa Krebet termasuk dalam wilayah kecamatan Pilang Kenceng yang merupakan tiga besar kasus terbanyak penyakit HIV/AIDS di kabupaten Madiun. Pemberian pengetahuan atau informasi terkait HIV/AIDS adalah salah satu cara efektif untuk menjelaskan tentang pencegahan dan penularan HIV/AIDS. Seseorang dengan pengetahuan yang baik dan benar tentang HIV/AIDS diharapkan dapat menurunkan bahkan menghilangkan stigma pada ODHA. Untuk itu diperlukan kerja keras petugas kesehatan maupun kader kesehatan dalam memberikan pendidikan kesehatan pada masyarakat desa Krebet. Pendidikan kesehatan pada hakikatnya adalah suatu kegiatan atau usaha untuk menyampaikan pesan kesehatan kepada masyarakat, kelompok atau individu. Harapan dengan adanya pesan tersebut masyarkat, keluarga atau individu dapat memperoleh pengetahuan tentang kesehatan yang lebih baik, (Notoadmodjo, 2005). Memfasilitasi pendidikan dalam konteks ini dapat dilakukan dalam serangkaian kegiatan seperti aktifitas diskusi, ceramah dan transformasi pengetahuan.

Persepsi masyarakat desa Krebet tentang ODHA pada sub aspek keberadaan ODHA di masyarakat responden berpersepsi positif namun pada pernyataan bahwa ODHA dapat dijadikan teman yang baik sejumlah $64 \%$ responden menyatakan tidak setuju. Sejumlah 34,4 $\%$ responden menyatakan upaya untuk melindungi diri dan keluarga dari penyebaran virus HIV/AIDS dengan menjauhi ODHA. Pada sub aspek stigma terhadap ODHA responden dalam hal ini masyarakat desa Krebet berpersepsi negative. Salah satu hambatan terbesar dalam pencegahan dan penanggulangan HIV/AIDS adalah masih tingginya stigma dan diskriminasi terhadap ODHA. Stigma berasal dari pikiran seorang individu atau masyarakat akibat dari perilaku amoral yang tidak dapat diterima oleh masyarakat. 57,4\% responden menyatakan ODHA adalah orang yang salah dalam pergaulan, 58,8\% responden menyatakan ODHA adalah pelanggan lokalisasi, 55,3\% responden menyatakan ODHA adalah penganut seks bebas dan $51,8 \%$ responden menyatakan ODHA adalah pengguna narkoba. Dari pernyataan tersebut dapat tergambarkan pernyataan negative masyarakat terhadap ODHA. Banyak yang beranggapan bahwa ODHA adalah orang yang bertanggung jawab terhadap penularan HIV/AIDS , (Maman, 2009). Hal inilah yang menyebabkan terjadinya penolakan masyarakat terhadap ODHA, adanya penolakan dari masyarakat tersebut mengakibatkan sebagian besar ODHA harus menyembunyikan statusnya.

Stigma terhadap ODHA memiliki dampak yang besar bagi program pencegahan dan penanggulangan HIV/AIDS termasuk kualitas hidup ODHA. Populasi beresiko akan merasa takut untuk melakukan test HIV karena apabila terungkap hasilnya reaktif akan menyebabkan mereka dikucilkan. Orang dengan HIV positif merasa takut untuk mengungkapkan statusnya dan memutuskan menunda pengobatan yang tentunya berdampak pada status kesehatan mereka dan penularan HIV tidak dapat dikontrol.

Bentuk stigma masyarakat desa Krebet terhadap ODHA adalah sebagai berikut : 30,3\% masyarakat setuju bahwa Odha adalah orang yang harus dijauhi karena menularkan penyakit yang mematikan, 36,76\% masyarakat setuju Odha adalah orang yang tidak mampu lagi untuk berkarya dan bekerja, 35,9\% masyarakat setuju bahwa Odha tidak perlu dilibatkan dalam kegiatn di masyarakat, 27,06 \% masyarakat desa Krebet setuju bila perlu Odha diusir dari desanya. Kondisi tersebut diatas menggambarkan stigma negative masyarakat desa Krebet terhadap keberadaan Odha. Stigma tersebut muncul karena ketidaktahuan masyarakat tentang informasi HIV/AIDS yang benar khususnya dalam mekanisme penularan penyakit HIV. 
Kesalahpahaman atau persespsi negative masyarakat terhadap Odha seringkali berdampak pada ketakutan masyarakat terhadap Odha, sehingga memunculkan penolakan terhadap Odha.

\section{KESIMPULAN}

Persepsi masyarakat desa Krebet kecamatan Pilang Kenceng kabupaten Madiun tentang HIV/AIDS adalah pada sub aspek pengertian HIV/AIDS berpersepsi negatif, sub aspek penyebab penyakit HIV/AIDS berpersepsi positif, sub aspek cara penularan HIV/AIDS berpersepsi negatif dan sub aspek pencegahan HIV/Aids berpersepsi positif.

Persespsi masyarakat desa Krebet kecamatan Pilang Kenceng kabupaten Madiun tentang Odha adalah pada sub aspek keberadaan Odha masyarakat Krebet berpersepsi positif dan sub aspek stigma terhadap Odha berpersepsi negatif.

Bentuk stigma masyarakat desa Krebet terhadap Odha adalah sebagai berikut : pernyataan bahwa Odha harus dijauhi (30,3\%), pernyataan bahwa Odha harus diusir $(27,06 \%)$, pernyataan bahwa Odha adalah orang yang tidak mampu untuk berkarya dan bekerja $(36,76 \%)$, pernyataan bahwa Odha tidak perlu dilibatkan dalam kegiatan di masyarakat $(35,9 \%)$.

Dari hasil penelitian disarankan agar masyarakat desa Krebet kecamatan PilangKenceng kabupaten Madiun untuk lebih aktif mencari informasi tentang HIV/AIDS terutama factor penyebaran dan pencegahan penyakit HIV/AIDS, bagi dinas kesehatan kabupaten Madiun diupayakan untuk meningkatkan penyuluhan dan sosialisasi tentang HIV/AIDS dalam upaya merubah stigma masyarakat terhadap ODHA khususnya lebih ditekankan pada cara penularan dan upaya pencegahan HIV/AIDS di masyarakat.

\section{DAFTAR PUSTAKA}

Direktorat Pengendalian Penyakit dan Penyehatan Lingkungan Departemen Kesehatan RI, Pedoman Nasional Perawatan, Dukungan dan Pengobatan bagi ODHA; Buku Pedoman untuk petugas kesehatan dan petugas lainnya, Jakarta,2006

Jawa Pos, Darah Ber HIV terdeteksi PMI, Radar Madiun tanggal 22 Maret 2014.

Jawa Pos, IV/AIDS Renggut 100 Nyawa; Kabupaten Madiun peringkat 10 Jatim, Radar Madiun tanggal 29 Maret 2014.

Kementrian Kesehatan RI 2011a, Laporan Perkembangan HIV/AIDS Triwulan 1 (Januari Maret 2011).http;//infopenyakit.org, diunduh tanggal 5 Januari 2016

KPAD Propinsi Jawa Timur, 2011, Mengenal Dan Menanggulangi HIV/AIDS Infeksi Menular Seksual dan Narkoba, Dinkes Propinsi Jatim

Mardhiati Retno \& Handayani Sarah, 2011, Peran Pendukung Sebaya Terhadap Peningkatan Mutu Hidup ODHA di Indonesia tahun 2011, spiritia_or.id/dok/ringkasan_penelitian_peran_dukungan_sebaya, di akses tanggal 2 Pebruari 2016

Mardhiati Retno \& Handayani Sarah, Peran Dukungan Terhadap Peningkatan Mutu Hidup ODHA di Indonesia Tahun 2011, Litbang Unmuh Prof. Hamka, Spiritia.or.id/Dok/ringkasan-penelitian-peran-dukungan-sebaya, diakses tanggal 15 Januari 2016

Noerliani D dkk, 2014, Faktor-Faktor Pendukung Kepatuhan Orang Dengan HIV/AIDS (ODHA) Dalam Minum Obat Antiretroviral Di kabupaten Madiun, Akper dr. Soedono Madiun.

Notoadmojo, 2006, Metodologi Penelitian Kesehatan, Edisi kedua, Jakarta, PT Rineka Cipta. Nursalam, 2016, Metodologi Penelitian Ilmu Keperawatan, Jakarta, Salemba Medika

Paryati T dkk, 2013, Faktor-faktor yang mempengaruhi stigma dan diskriminasi kepada ODHA (Orang dengan HIV/AIDS) oleh petugas kesehatan : kajianliteratur, http://pustaka.unpad.ac.id/wp-content/upoad/2013/02/pustaka unpad-faktormempegaruhi-stigma-ODHA.pdf, diakses tanggal 20 Januari 
Peraturan Menteri Dalam Negeri No 20 Tahun 2007 Tentang Pedoman Umum Pembentukan Komisi Penanggulangan AIDS dan Pemberdayaan Masyarakat Dalam Rangka Penanggulangan HIV dan AIDS di Daerah

Pieter Z H \& Lubis LH, 2010, Pengantar Psikologi Dalam Keperawatan, Jakarta, Kencana

Reynold R.Purba, Faktor-faktor yang berhubungan dengan kepatuhan pengobatan minum ARV pada pasien HIV di Kabupaten Mimika Propinsi Papua Tahun 2012, Thesis UI

Sugiyono, 2007, Metode Penelitian Kuantitatif, Kualitatif dan $R \&$ D, Bandung, CV Alfabeta. Sunaryo,2013, Psikologi Untuk Keperawatan Edisi 2, Jakarta EGC

Walter $\mathrm{H}$ et, Understanding the fasilitators and barieres of antiretroviral adherence in Peru : Qualitatif study, BMC public Health 2010

Waluyo Agung dkk, Persepsi Pasien dengan HIV/AIDS dan keluarganya tentang HIV/AIDS dan Stigma Masyarakat Terhadap Pasien Pasien HIV/AIDS, Jurnal Kesmas.ui.ac.id/index.php/kesmas/article, di akses tanggal 25 Januari 